\title{
SISTEM PAKAR MENDIAGNOSA PENYAKIT KOLESTEROL PADA REMAJA DENGAN METODE CERTAINTY FACTOR (CF) BERBASIS WEB
}

\author{
Hengki Tamando Sihotang \\ Program Studi Teknik Infotmatika \\ STMIK Pelita Nusantara Medan,Jl. Iskandar Muda No.1 Medan, Sumatera Utara 20154, Indonesia
}

hengki_tamando@yahoo.com

\begin{abstract}
Abstrak
Saat ini komputer telah banyak digunakan dalam dunia medis untuk membantu diagnosis suatu penyakit. Penyakit yang paling penting dan sering ditemukan adalah kolestrol. Pencegahan penyakit lebih baik dari pada pengobatannya. Oleh karena itu, pencegahan penyakit kolestrol ini diawali dengan pendiagnosaan dini.

Salah satu teknik dalam mendiagnosis penyakit kolestrol ini adalah sistem pakar. Maka dari itu penelitian ini bertujuan menyusun sebuah sistem pakar yang digunakan untuk diagnosa awal penyakit kolestrol berdasarkan gejala yang dirasakan. Sistem akan menampilkan Besarnya kepercayaan gejala tersebut terhadap kemungkinan penyakit yang diderita pengguna. Besarnya nilai kepercayaan tersebut merupakan hasil perhitungan dengan menggunakan metode Certainty Factor(CF). Representasi pengetahuan yang digunakan pada penelitian ini adalah production rule. Metode inferensi yang digunakan untuk mendapatkan konklusi yaitu penalaran maju (forward chaining).
\end{abstract}

Kata Kunci: Aplikasi, Penyakit, Diagnosis, Certainty Factor (CF).

\section{PENDAHULUAN}

Sistem pakar adalah sistem berbasis komputer yang mampu menyamai atau meniru kemampuan seorang pakar dalam menyelesaikan suatu masalah. Sistem ini dirancang untuk meniru keahlian seorang pakar dalam menjawab pertanyaan dan menyelesaikan suatu permasalahan baik di bidang kesehatan atau kedokteran, bisnis, ekonomi dan sebagainya. Peran penting seorang pakar dapat diganti oleh program komputer yang prinsip kerjanya untuk memberikan solusi seperti yang dilakukan oleh pakar Certainty Factor rnerupakan salah satu teknik yang digunakan untuk mangatasi ketidakpastian dalam pengambilan keputusan. Dalam menghadapi suatu masalah, sering ditemukan jawaban yang tidak memiliki kepastian penuh.

Kolesterol adalah lemak yang terdapat di dalam aliran darah atau sel tubuh yang sebenarnya dibutuhkan untuk pembentukan dinding sel dan sebagai bahan baku beberapa harmon. Kolestrol yang normal harus di bawah $200 \mathrm{mg} / \mathrm{dl}$. Apabila di atas $240 \mathrm{mg} / \mathrm{dl}$, maka berisiko tinggi terkena penyakit seperti serangan Jantung atau Stroke, Kolestrol secara alami bisa dibentuk oleh tubuh, selebihnya didapat dari makanan hewani, seperti daging, unggas, ikan, margarin, keju, dan susu. Kolestrol tidal larut dalam darah sehingga perlu berikatan dengan pengangkutnya, yaitu lipoprotein. Oleh karena itu pula kolestrol dibedakan menjadi Low-Density
Lipopprotein (LDL) dan High-Denzsity Lipoprotein (HDL).

Kolesterol tinggi mempengaruhi sekitar 15 persen dari remaja, dan seringnya masalah ini terus berkembang. Sekitar 1.5 persen dari remaja menderita kolesterol tinggi karena kondisi tersebut juga ada di dalam keluarga rnereka. kadar kolesterol yang dapat diterima dalam tubuh remaja adalah antara $120 \mathrm{mg} / \mathrm{dl}$, dari $170 \mathrm{mg} / \mathrm{dL}$ untuk kolesterol total.

Metode certainty factor (CF) merupakan metode yang mendefinisikan ukuran kapasitas terhadap suatu fakta atau aturan, dalam mengekspresikan tingkat keyakinan seorang pakar terhadap suatu masalah yang sedang dihadapi, certainty factor $(C F)$ memperkenalkan konsep belief atau keyakinan dan disbelife atau ketidakyakinan. Oleh karena itu agar tidak ada kesalahan diagnosa dan mempermudah masyarakat untuk mengetahui sejak dini penyakit yang diderita nada anak dan agar tidak terlambat mendapatkan pengobatan dikarenakan seorang dokter atau pakar memiliki keterbatasan waktu. Maka dibangun sesuatu sistem yang dapat membantu menyelesaikan masalah dalam sistem pakar dengan menggunakan metode certainty factor $(C F)$.

Penelitian yang sama dilakukan oleh Nur Anzas Sari dari kampus STMIK Budidarma Medan dengan judul Sistem Pakar Mendiagnosa Penyakit Demam Berdarah Menggunakan Metode Certainty Factor membahas bahwa sistem pakar adalah sistem yang mampu menirukan penalaran 
seorang pakar agar komputer dapat menyelesaikan masalah seperti yang biasa dilakukan oleh para ahli. Sistem pakar untuk mendiagnosa penyakit demam berdarah ini merupakan suatu sistem pakar yang dirancang sebagai alat bantu untuk mendiagnosa pennyakit demam berdarah dengan basis pengetahuan yang dinamis.

\section{LANSADAN TEORI}

\subsection{Pakar ( Expert)}

Pakar adalah seseorang yang mempunyai pengetahuan, pengalaman, dan metode khusus, serta mampu menerapkannya untuk memecahkan masalah atau memberi nasehat. Seorang pakar harus mampu menjelaskan untuk mempelajari hal -hal baru yang berkaitan dengan topik permasalahan, jika perlu harus mampu menyusun kembali pengetahuan-pengetahuan yang didapatkan, dan dapat memecahkan aturanaturan serta menentukan relevansi kepakarannya. Jadi seorang pakar harus mampu melakukan kegitan-kegiatan sebagai berikut:

1. Mengenali dan memformulasikan permasalahan

2. Memecahkan permasalahan secara cepat dan tepat

3. Menerangkan pemecahannya

4. Belajar dari pengalaman

5. Merektrukturisasi pengetahuan

6. Memecahkan aturan - aturan

Menentukan relevansi (T. Sutojo, 2011 : 163)

\subsection{Sistem Pakar}

Sistem Pakar (Expert System) adalah aplikasi berbasis komputer yang digunakan untuk menyelesaikan masalah sebagaimana yang dipikirkan oleh pakar. Pakar yang dimaksud di sini adalah orang yang mempunyai keahlian khusus yang dapat menyelesaikan masalah yang tidak dapat diselesai kan oleh orang awam. Sebagai contoh, dokter adalah seorang pakar yang mampu mendiagnosa penyakit yang diderita pasien serta dapat memberikan penetalaksanaan terhadap penyakit tersebut. (T. Sutojo, 2011: 159)

Tidak semua orang dapat mengambil keputusan mengenai diagnosa dan memberikan penetalaksanaan suatu penyakit. Contoh yang lain, montir adalah seorang yang mempunyai keahlian dan pengalaman dalam menyelesaikan kerusakan mesin motor atau mobil; psikolog adalah orang yang ahli dalam memahami kepribadian seseorang, dan laian-lain (T. Sutojo, 2011: 160).

Sistem Pakar, yang mencoba memecahkan masalah yang biasanya hanya bisa dipecahkan oleh seorang pakar, dipandang berhasil ketika mampu mengambil keputusan seperti yang dilakukan oleh pakar asli nya baik dari sisi proses pengambilan keputusan maupun hasil keputusan yang diperoleh.

Sebuah sistem pakar memiliki 2 koponen utama yaitu berbasis pengetahuan dan mesin inferensi. Berbasis pengetahuan merupakan tempat penyimpanan pengetahuan dalam memeori komputer, dimana pengetahuan ini diambil dari pengetahuan pakar. Sedangkan mesin inferensi merupakan otak dari apliakasi sistem pakar, bagian inilah yang menuntun user untuk memasukkan fakta sehingga diperoleh suatau kesimpulan. (T. Sutojo 2011: 160)

\subsection{Diagnosa}

Diagnosa sebagaimana halnya dengan penelitian-penelitian ilmiah, didasarkan atas metode hipotesis. Dengan metode hipotesis ini menjadikan penyakit-penyakit begitu mudah dikenali hanya dengan suatu kesimpulan diagnostik. Diagnosa dimulai sejak permulaan wawancara medis dan berlangsung selama melakukan pemeriksaan fisik. Dari diagnosa tersebut akan diperoleh pertanyaan - pertanyaan yang terarah, perincian pemeriksaan fisik yang dilakukan untuk menentukan pilihan testes serta pemeriksaan khusus yang akan dikerjakan. Data yang berhasil dihimpun akan dipertimbangkan dan diklasifikasikan berdasarkan keluhan-keluhan dari pasien serta hubungannya terhadap penyakit tertentu. Berdasarkan gejala-gejala serta tandatanda yang dialami oleh penderita, maka penegakkan diagnosa akan lebih terpusat pada bagian-bagian tubuh tertentu. Dengan demikian penyebab dari gejala-gejala dan tanda-tanda tersebut dapat diketahui dengan mudah dan akhirnya diperoleh kesimpulan awal mengenai penyakit tertentu (Sutikno,2008). (Julianto Lemantara, Jurnal Aplikasi Sistem Pakar Diagnosa Penyakit, 2008).

\subsection{Kolestrol}

Kolestrol adalah lemak berwarna kekuningan berbentuk seperti lilin yang diproduksi oleh tubuh manusia, terutama di dalam lever (hati). Kolestrol terbentuk secara ilmiah. Dari segi ilmu kimia, kolestrol merupakan senyawa lemak kompleks yang dihasilkan oleh tubuh dengan bermacam macam fungsi antara lain untuk membuat hormon seks, hormon korteks adrenal, vitamin D, dan untuk membuat garam empedu yang membantu usus untuk menyerap lemak. Jadi, jika takarannya pas atau normal, kolestro berperan penting dalam tubuh. Namun, jika terlalu banyak, kolestrol dalam aliran darah justru berbahaya bagi tubuh (dr, Sri Nilawati, SpKO, Care Your Self Kolestrol, 2008 : 12).

Kolestrol akan menyebabkan zat tersebut bereaksi dengan zat - zat lain dalam tubuh dan akan mengendap dalam pembuluh darah arteri. Hal yang akan terjadi selanjutnya adalah 
penyempitan dan pengerasan pembuluh darah (atherosklerosis) hingga penyumbatan dan pemblokiran aliran darah. Akibatnya, jumlah suplai darah ke jantung berkurang, terjadi sakit atau nyeri dada yang disebut angina, bahkan menjurus ke serangan jantung (dr, Sri Nilawati, SpKO, Care Your Self Kolestrol, 2008 : 12).

Kolestrol berasal dari organ binatang, terutama bagian otak, kuning telur, dan jeroan. Demikian juga produski yang berasal darinya, seperti susu asli, keju, mentega, dan lain - lain. Sementara bahkan makanan yag bersumber dari tumbuh - tumbuhan tidak mengandung kolestrol. Dengan demikian, diperkirakan dua per tiga dari seluruh kolestrol yang ada dalam tubuh diproduksi oleh hati atau lever. Jadi, sspertiga dari seluruh kolestrol dalam tubuh diserap oleh sistem pencernaan dari makanan yang dikonsumsi. Kolestrol menyebar keseluruh tubuh setelah dibentuk oleh hati. Begitu lemak yang berfungsi menyediakan energi bagi tubuh dan dicerna keduanya terikat kedalam satu ikatan yang kemudian terbawa ke berbagai tempat di seluruh jaringan tubuh melalui darah (dr, Sri Nilawati, SpKO, Care Your Self Kolestrol, 2008 : 12)

\subsection{Gejala - Gejala Kolestrol}

Gejala kolesterol khusnya pada remaja kadang tidak disadari oleh banyak orang dan kadang diabaikan. Kolesterol memang dibutuhkan oleh tubuh, tapi sebenarnya tanpa asupan kolesterol dari luar pun kebutuhannya sudah terpenuhi dengan baik. Karena 80 persen kolesterol dihasilkan dari dalam tubuh (organ hati) dan 20 persen sisanya dari makanan ( Annisa Trie Anna, Jurnal Hubungan Kadar Kolestrol LDL Dengan Tipe Stroke, 2012)

Gejala kolesterol kebanyakan dialami karena pola makan dan gaya hidupnya sehingga menimbulkan kolesterol tinggi. Seseorang dikatakan memiliki kadar kolesterol normal jika ukurannya 160-200 mg sedangkan masuk kondisi berbahaya jika sudah di atas $240 \mathrm{mg}$ karena bisa menyebabkan stroke (Annisa Trie Anna, Jurnal Hubungan Kadar Kolestrol LDL Dengan Tipe Stroke, 2012).

Orang yang mengalami kolesterol tinggi kadang tidak menunjukkan gejala khusus. Tapi ada gejala khusus pada orang yang kena kolesterol tinggi. Gejala kolesterol tinggi yaitu:

1. Rasa sakit atau pegal di tengkuk kepala bagian belakang.

2. Pegal ini juga sampai ke pundak

3. Kaki bengkak

4. Mudah capai

5. Gampang mengantuk (Annisa Trie Anna, Jurnal Hubungan Kadar Kolestrol LDL Dengan Tipe Stroke, 2012)
Yang paling akurat untuk mengetahui apakah orang menderita kolesterol tinggi atau tidak tentu saja dengan tes laboratorium. Jika kadar kolesterol melebihi $240 \mathrm{mg}$, itu artinya sudah batas peringatan yang harus diturunkan.Seseorang dikatakan memiliki kadar kolesterol normal jika ukurannya 160-200 mg sedangkan masuk kondisi berbahaya jika sudah di atas $240 \mathrm{mg}$ karena bisa menyebabkan stroke. Meskipun kolesterol tinggi itu sendiri tidak secara langsung menyebabkan kelelahan, tapi kondisi-kondisi yang ditimbulkan dapat membuat orang lebih mudah lelah alias capek (Annisa Trie Anna, Jurnal Hubungan Kadar Kolestrol LDL Dengan Tipe Stroke, 2012)

Kolesterol tinggi juga memiliki dampak pada tubuh. Kadar kolesterol yang tinggi merupakan faktor risiko penyakit jantung dan pembuluh darah. Risiko terburuknya, gumpalan-gumpalan lemak bisa menyumbat aliran darah sehingga bisa memicu kematian akibat serangan jantung atau stroke.

Untuk mengantisipasi gejala kolesterol tinggi dapat dilakukan sejak dini. Dengan olah raga teratur dan mengkonsumsi makanan berserat dan yang kaya dengan antioksidan ((Annisa Trie Anna, Jurnal Hubungan Kadar Kolestrol LDL Dengan Tipe Stroke, 2012).

\subsection{Certainty Factor}

Faktor kepastian (certainty factor) diperkenalkan oleh Shortliffe Buchanan dalam pembuatan MYCIN (Wesley, 1984). Certainty factor (CF) merupakan nilai parameter klinis yang diberikan MYCIN untuk menunjukkan besarnya kepercayaan. Dalam menghadapi suatu masalah sering ditemukan jawaban yang tidak memiliki kepastian penuh. Ketidakpastian ini bisa berupa probabilitas atau kebolehjadian yang tergantung dari hasil suatu kejadian. Hasil yang tidak pasti disebabkan oleh dua faktor yaitu aturan yang tidak pasti dan jawaban pengguna yang tidak pasti atas suatu pertanyaan yang diajukan oleh sistem. Hal ini sangat mudah dilihat pada system diagnosis penyakit, dimana pakar tidak dapat mendefinisikan tentang hubungan antara gejala dengan penyebabnya secara pasti, dan pasien tidak dapat merasakan suatu gejala dengan pasti pula. Pada akhirnya ditemukan banyak kemungkinan diagnosis (T. Sutojo, 2011 : 194).

Sistem pakar harus mampu bekerja dalam ketidakpastian. Sejumlah teori telah ditemukan untuk menyelesaikan ketidakpastian,termasuk diantaranya probabilitas klasik (classical probability), probabilitas Bayes (Bayesian probability), teori Hartley berdasarkan himpunan klasik (Hartley theory based on classical sets), teori Shannon berdasarkan pada probabilitas (Shannon theory based on probability), teori Dempster-Shafer (Dempster-Shafer theory), teori fuzzy Zadeh (Zadeh.s fuzzy theory) dan faktor 
kepastian (certainty factor). Dalam penelitian ini yang digunakan adalah factor kepastian ( $\mathrm{T}$. Sutojo, 2011 : 194).

Adapun Faktor kepastian merupakan suatu metode yang digunakan untuk mengukur suatu keyakinan seseorang. Inputnya adalah berupa kepastian dari pakar serta kepastian dari user. (T. sutojo, 2011 : 194)

\section{a. Probabilitas Dan Certainty Factor.}

Certainty factor didefenisikan sebagai persamaan berikut :

$\mathrm{CF}(\mathrm{H}, \mathrm{E})=\mathrm{MB}(\mathrm{H}, \mathrm{E})-\mathrm{MD}(\mathrm{H}, \mathrm{E})$

$\mathrm{CF}(\mathrm{H}, \mathrm{E})$ : certainty factor dari hipotesis $\mathrm{H}$ yang dipengaruhi oleh gejala (evidence) E. Besarnya CF berkisar antara -1 sampai 1. Nilai -1 menunjukkan ketidakpercayaan mutlak sedangkan nilai 1 menunjukkan kepercayaan mutlak $\mathrm{MB}(\mathrm{H}, \mathrm{E})$ : ukuran kenaikan kepercyaan (measure of increased belief) terhadap hipotesis $\mathrm{H}$ yang dipengaruhi oleh gejala $\mathrm{E}$.

$\mathrm{MD}(\mathrm{H}, \mathrm{E})$ : ukuran kenaikan ketidakpercayaan (measure of increased disbelief) terhadap hipotesis $\mathrm{H}$ yang dipengaruhi oleh gejala $\mathrm{E}$.

Bentuk dasar rumus certainty factor, adalah sebuah aturan jika $\mathrm{E}$ maka $\mathrm{H}$ seperti ditunjukkan oleh persamaan berikut :

$\mathrm{CF}(\mathrm{H}, \mathrm{e})=\mathrm{CF}(\mathrm{E}, \mathrm{e}) * \mathrm{CF}(\mathrm{H}, \mathrm{E})$

Dimana :

CF (H, E) : certainty Factor hipotesis yang dipengaruhi oleh evidence e.

CF (E, e) : Certainty Factor evidence E yang dipengaruhi oleh evidence e.

$\mathrm{CF}(\mathrm{H}, \mathrm{E})$ : Certainty Factor hipotesis dengan asumsi evidence diketahui dengan pasti, yaitu ketika $\mathrm{CF}(\mathrm{E}, \mathrm{e})=1$. Jika Evidence pada antecedent diketahui dengan pasti maka persamaannya akan menjadi : $\mathrm{CF}(\mathrm{E}, \mathrm{e})=\mathrm{CF}($ $\mathrm{H}, \mathrm{E})$.

Nilai CF (rule) didapat dari interpretasi "term" dari pakar, yang diubah menjadi nilai CF tertentu sesuai tabel berikut:

Table I. nilai Certainty Factor

\begin{tabular}{|l|l|}
\hline Uncertain Term & CF \\
\hline Pasti tidak & -1.0 \\
\hline Hampir pasti tidak & -0.8 \\
\hline Kemungkinan besar tidak & -0.6 \\
\hline Mungkin tidak & -0.4 \\
\hline Tidak tahu & -0.2 to 0.2 \\
\hline Mungkin & 0.4 \\
\hline Kemungkinan besar & 0.6 \\
\hline Hampir pasti & 0.8 \\
\hline Pasti & 1.0 \\
\hline
\end{tabular}

b. Perhitungan Certainty Factor Gabungan.

Secara umum, rule direpresentasikan dalam bentuk sebagai berikut :

IF $E_{1}$ AND $E_{2} \ldots \ldots$ AND $E_{n}$ THEN H (CF rule) Atau

IF $E_{1}$ OR $E_{2} \ldots \ldots \ldots$ OR $E_{n}$ THEN H (CF rule)
Dimana :

$\mathrm{E}_{1} \ldots \mathrm{E}_{\mathrm{n}}$ : fakta - fakta (evidence) yang ada

$\mathrm{H}$ : Hipotesis atau konklusi yang dihasilkan

CF rule : Tingkat keyakinan terjadinya hipotesis $\mathrm{H}$ akibat adanya fakta - fakta $E_{1} \ldots E_{n}$ (T. Sutojo, 2011 :196)

\section{c. Kelebihan dan Kekurangan Metode Certainty Factor.}

Kelebihan metode certainty factor adalah :

1. Metode ini cocok dipakai dalam system pakar yang mengandung ketidakpastian.

2. Dalam sekali proses perhitungan hanya dapat mengolah 2 data saja sehingga keakuratan data dapat terjaga.

Sedangkan kekurangan metode certainty factor adalah :

1. Pemodelan ketidakpastian yang menggunakan perhitungan metode certainty factor biasanya masih diperdebatkan.

2. Untuk data lebih dari 2 buah, harus dilakukan beberapa kali pengolahan data. (T. sutojo, 2011 : 204).

\section{ANALISA DAN RANCANGAN PROGRAM \\ 3.1 Analisa}

Penerapan teknologi Artificial Inteligence ada beberapa aturanyang sering digunakan, salah satunya adalah certainty factor. Certainty factor merupakan perhitungan tingkat kepastian terhadap kesimpulan yang diperoleh yang dihitung berdasarkan nilai probabilitas penyakit karena adanya evident atau gejala. Perhitungan dengan menggunakan metode ini, dalam sekali hitung hanya dapat mengolah dua jenis data saja sehingga keakuratannya dapat terjaga.

Cara diagnosa dokter tersebut memiliki persamaan dengan model aplikasi diagnosis penyakit kolestrol dengan menggunakan certainty factor. Representasi penafsiran analisis dokter dinyatakan dalam bentuk rule sebagai tempat lmenyimpan pengetahuan dan analisa dari dokter dalam aplikasi. Keduanya dalam menyimpulkan suatu keputusan mengacu pada suatu fakta-fakta gejala yang didapatkan yang diberikan oleh pasien, pada certainty factor akan dibarukan nilai tingkat keyakinan yang akan digunakan untuk mengukur tingkat kepastian suatu penyakit yang dialami pasien seperti yang dilakukan dokter.

\subsection{Gejala Penyakit Kolestrol Pada Remaja}

Data-data dasar yang telah didapatkan digunakan dalam operasional konsultasi dan sebagai bahan untuk merepresentasikan pengetahuan. Dalam sistem pakar untuk mendiagnosis gejala - gejala penyakit kolestrol pengetahuan direpresentasikan dengan menggunakan kaidah produksi. 
Secara default sistem ini memiliki 4 rule diagnosis penyakit yang nantinya masih bisa ditambahkan oleh pakar. Daftar Rule (aturan) diagnosis pada system ini ditunjukkan pada table berikut:

Tabel II. Daftar Rule Diagnosis penyakit.

\begin{tabular}{|c|c|}
\hline ID & RULE (ATURAN) \\
\hline 1. & $\begin{array}{l}\text { IF } \quad \text { Rasa sakit pegal di kepala } \\
A N D \text { Kaki bengkak } \\
A N D \text { Gampang mengantuk } \\
A N D \text { Mudah capek } \\
\text { AND Pegal sampai ke pundak } \\
\text { THEN Kolestol HDL ( kolestrol baik ) }\end{array}$ \\
\hline 2. & $\begin{array}{l}\text { IF Kaki bengkak } \\
\text { AND mudah capek } \\
\text { AND gampang mengantuk } \\
\text { AND Kadar kolestrol di atas } 120-200 \mathrm{Mg} \\
\text { THEN Kolestrol LDL ( kolestrol jahat ) }\end{array}$ \\
\hline 3. & $\begin{array}{l}\text { IF Kadar kolestrol di atas } 120-200 \\
\mathrm{Mg} \\
\text { AND pegal sampai ke pundak } \\
\text { THEN Kolestrol HDl ( kolestrol baik ) }\end{array}$ \\
\hline 4. & $\begin{array}{l}\text { IF Rasa sakit pegal di kepala } \\
\text { AND Kaki bengkak } \\
\text { AND mudah capek } \\
\text { THEN Kolestrol HDL( kolestrol baik ) }\end{array}$ \\
\hline 5 & $\begin{array}{l}\text { IF Rasa sakit pegal di kepala } \\
\text { AND mudah capek } \\
\text { AND gampang mengantuk } \\
\text { AND Kadar kolestrol di atas } 120-200 \mathrm{Mg} \\
\text { THEN Kolestrol LDL ( kolestrol jahat ) }\end{array}$ \\
\hline 6 & $\begin{array}{l}\text { IF } \quad \text { Rasa sakit pegal di kepala } \\
\text { AND } \text { Rasa sakit pegal di kepala } \\
\text { AND Kaki bengkak } \\
\text { THEN Kolestrol LDL ( kolestrol jahat ) }\end{array}$ \\
\hline 7 & $\begin{array}{l}\text { IF Rasa sakit pegal di kepala } \\
\text { AND Rasa sakit pegal di kepala } \\
\text { AND Kaki bengkak } \\
\text { AND Kadar kolestrol di atas } 120-200 \mathrm{Mg} \\
\text { THEN Kolestrol LDL ( kolestrol jahat ) }\end{array}$ \\
\hline 8 & $\begin{array}{l}\text { IF Kaki bengkak } \\
\text { AND Gampang mengantuk } \\
\text { AND Mudah capek } \\
\text { AND Pegal sampai ke pundak } \\
\text { THEN Kolestol HDL ( kolestrol baik ) }\end{array}$ \\
\hline
\end{tabular}

Tabel II Tabel Persentase Kesimpulan

\begin{tabular}{|c|c|l|}
\hline No & $\begin{array}{c}\text { Tingkat } \\
\text { persentase }\end{array}$ & \multicolumn{1}{|c|}{ Nilai Keyakinan } \\
\hline 1 & $0 \%-50 \%$ & $\begin{array}{l}\text { Sedikit kemungkinan atau } \\
\text { kemungkinan kecil }\end{array}$ \\
\hline 2 & $51 \%-79 \%$ & Pasti \\
\hline 3 & $80 \%-99 \%$ & Kemungkinan Besar \\
\hline 4 & $100 \%$ & Sangat yakin \\
\hline
\end{tabular}

Selanjutnya dilakukan penetapan basis pengetahuan yang digunakan untuk menentukan aturan $C F$ sebagai dasar untuk menentukan pasien mengidap penyakit kolestrol atau tidak, di mana setiap rule memiliki satu bagian, misalnya IF $A$ Then $B$. Aturan $C F$ yang digunakan dapat dilihat pada tabel IV

Tabel IV Aturan $C F$

\begin{tabular}{|c|c|c|c|c|c|c|c|c|}
\hline \multirow{2}{*}{\multicolumn{2}{|c|}{ E }} & \multirow[b]{2}{*}{ Ciri-ciri } & \multirow{2}{*}{ A } & \multirow{2}{*}{ B } & \multirow{2}{*}{$\mathrm{D}$} & \multirow{2}{*}{$\mathrm{F}$} & \multicolumn{2}{|c|}{ Maka } \\
\hline & & & & & & & + & - \\
\hline E1 & IF & $\begin{array}{l}\text { Rasa sakit pegal } \\
\text { di kepala }\end{array}$ & & $\sqrt{ }$ & & & $\sqrt{ }$ & \\
\hline $\mathrm{E} 2$ & IF & $\begin{array}{l}\text { Pegal sampai ke } \\
\text { puncak }\end{array}$ & & $\sqrt{ }$ & & & $\sqrt{ }$ & \\
\hline E3 & IF & $\begin{array}{l}\text { Gampang } \\
\text { mengantuk }\end{array}$ & $\sqrt{ }$ & & & & & $\sqrt{ }$ \\
\hline E4 & IF & Kaki bengkak & $\sqrt{ }$ & & & & & $\sqrt{ }$ \\
\hline E5 & IF & Mudah capek & $\sqrt{ }$ & & & & & $\sqrt{ }$ \\
\hline E6 & IF & $\begin{array}{l}\text { Kadar kolestrol } \\
\text { di atas } 120- \\
200 \mathrm{Mg} / \mathrm{dl}\end{array}$ & & & $\sqrt{ }$ & & $\sqrt{ }$ & \\
\hline
\end{tabular}

Keterangan :

a. Sedikit kemungkinan atau kemungkinan kecil Hampir pasti tidak

b. Pasti

Kemungkinan Besar mungkin

\subsection{Ciri Gejala Penyakit Kolestrol Pada \\ Remaja}

Untuk sistem ini, tingkat kepastian sistem terhadap kesimpulan yang diperoleh dihitung berdasarkan nilai probabilitas penyakit karena adanya evidence/gejala tertentu. Sebagai penalaran perumusan ketidak pastian,dapat memberikan nilai dari setiap gejala untuk penyakit penderita kolestrol dengan nilai gejala seperti

Tabel V Ciri-ciri Gejala Kolestrol

\begin{tabular}{|c|c|l|c|}
\hline No & Kode & $\begin{array}{l}\text { Gejala- Gejala } \\
\text { kolestrol }\end{array}$ & $\begin{array}{c}\text { Nilai } \\
\text { Pakar }\end{array}$ \\
\hline $\mathbf{1}$ & E1 & $\begin{array}{l}\text { Rasa sakit pegal di } \\
\text { kepala }\end{array}$ & $\mathbf{0 . 6}$ \\
\hline $\mathbf{2}$ & E2 & $\begin{array}{l}\text { Pegal sampai ke } \\
\text { pundak }\end{array}$ & $\mathbf{0 . 6}$ \\
\hline $\mathbf{3}$ & $\mathbf{E 3}$ & Gampang,rnengantuk & $\mathbf{0 . 1}$ \\
\hline $\mathbf{4}$ & $\mathbf{E 4}$ & Kaki bengkak & $\mathbf{0 . 4}$ \\
\hline $\mathbf{5}$ & $\mathbf{E 5}$ & Mudah capek & $\mathbf{0 . 2}$ \\
\hline $\mathbf{6}$ & $\mathbf{E 6}$ & $\begin{array}{l}\text { Kadar kolestrol di atas } \\
\text { 120-240 Mg/dl }\end{array}$ & $\mathbf{1 . 0}$ \\
\hline
\end{tabular}

a) Rasa sakit pegal di kepala $=0,6$ dianggap dengan: " $E_{1}$ "

b) Pegal sampai ke pundak $=0,6$ dianggap dengan : " $\mathrm{E}_{2}$ "

c) Gampang mengantuk = -0,1 dianggap dengan : "E $\mathrm{E}_{3}$ "

d) Kaki bengkak = 0,4 dianggap dengan : " $E_{4}$ "

e) Mudah capek $=0,4$ dianggap dengan : " $E_{5}$ " 
f) Kadar Kolestrol di atas $120-200 \mathrm{Mg} / \mathrm{dl}=$ 1.0 dianggap dengan : " $\mathrm{E}_{6}$ "

Adapun logika metode certainty factor pada sesi konsultasi sistem, pengguna konsultasi diberi pilihan jawaban yang masing-masing memiliki bobot sebagai berikut :

Tabel VI Bobot Keyakinan ciri - ciri gejala Kolestrol

\begin{tabular}{|c|l|c|l|}
\hline No & Nama gejala & $\begin{array}{c}\text { Tingkat } \\
\text { persentase }\end{array}$ & $\begin{array}{l}\text { Keyakin } \\
\text { an }\end{array}$ \\
\hline 1 & $\begin{array}{l}\text { Rasa sakit di } \\
\text { kepala }\end{array}$ & $60 \%$ & pasti \\
\hline 2 & $\begin{array}{l}\text { Pegal } \\
\text { sampai ke } \\
\text { pundak }\end{array}$ & $60 \%$ & Pasti \\
\hline 3 & $\begin{array}{l}\text { Gampang } \\
\text { mengantuk }\end{array}$ & $10 \%$ & $\begin{array}{l}\text { Sedikit } \\
\text { kemung } \\
\text { kinan }\end{array}$ \\
\hline 5 & $\begin{array}{l}\text { Kaki } \\
\text { bengkak }\end{array}$ & $\begin{array}{l}\text { Mudah } \\
\text { capek }\end{array}$ & $\begin{array}{l}\text { Sedikit } \\
\text { kemung } \\
\text { kinan }\end{array}$ \\
\hline 6 & $\begin{array}{l}\text { Kadar } \\
\text { kolesrol 120 } \\
-240 \mathrm{Mg} / \mathrm{dl}\end{array}$ & $100 \%$ & $\begin{array}{l}\text { Sedikit } \\
\text { kemung } \\
\text { kinan }\end{array}$ \\
\hline
\end{tabular}

3.4. Algoritma Sistem Pakar untuk mendiagnosis penyakit kolestrol Algoritma

Berikut ini rincian langkah-langkah

1. Mulai

2. Ambil semua gejala yang menentukan aturan nama penyakit.

Bentuk dari query untuk melakukan pencarian gejala adalah

3. Tanyakan semua gejala penyakit kepada pengguna.

4. Jika gejala habis maka lanjut ke langkah 6, jika tidak kembali ke langkah 2.

5. Simpan jawaban (CF) pengguna ke dalam tabel cek gejala.

6. Cari nilai minimum dari sekumpulan $\mathrm{CF}$ pengguna dalam tabel cek gejala yang memiliki IDRule yang sama.

7. Cari nilai CFFinal dari tiap-tiap aturan nama penyakit.

Bentuk rumus pencariannya :

CFFinal $=$ CFUser $*$ CF Pakar

8. Tampilakan kesimpulan penyakit

9. Selesai.

Algoritma sistem pakar untuk mendiagnosis penyakit kolestrol dengan metode Certainty Factor dapat digambarkan dalam bentuk flowchart dapat dilihat seperti gambar berikut :

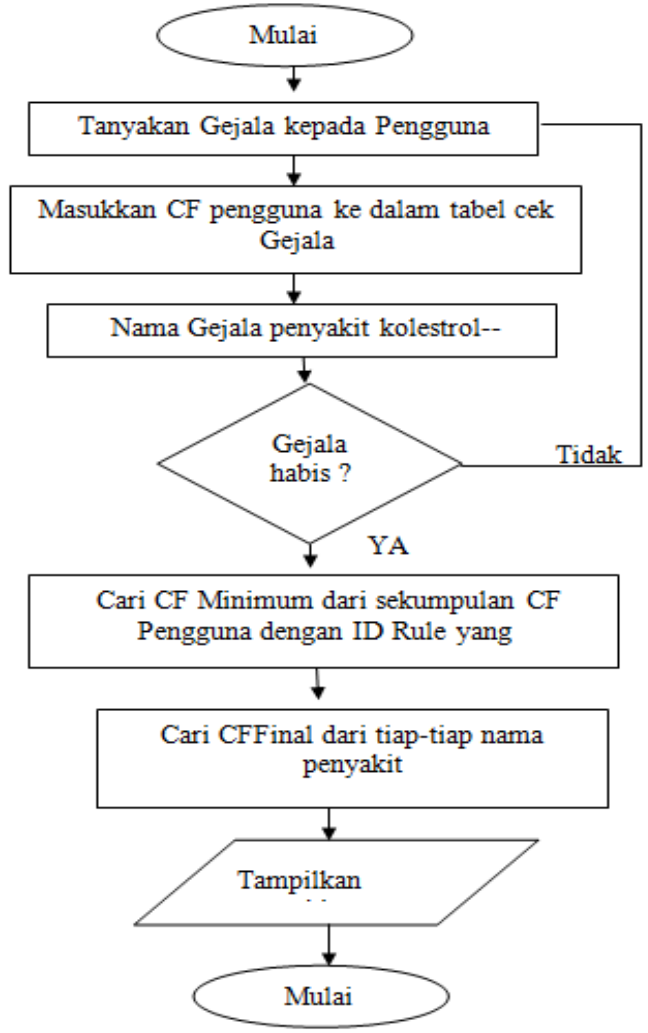

Gambar 1. Algoritma Sistem pakar untuk mendiagnosis penyakit kolestrol

\subsection{Perancangan Use Case Diagram}

Use case merupakan fungsional dari suatu sistem, sehingga custumer atau pengguna sistem paham dan mengerti mengenai kegunaan sistem yang akan dibangun. Use case sistem pakar untuk mendiagnosis penyakit kolestroldapat dilihat dalam gambar 2 sebagai berikut dibawah ini :

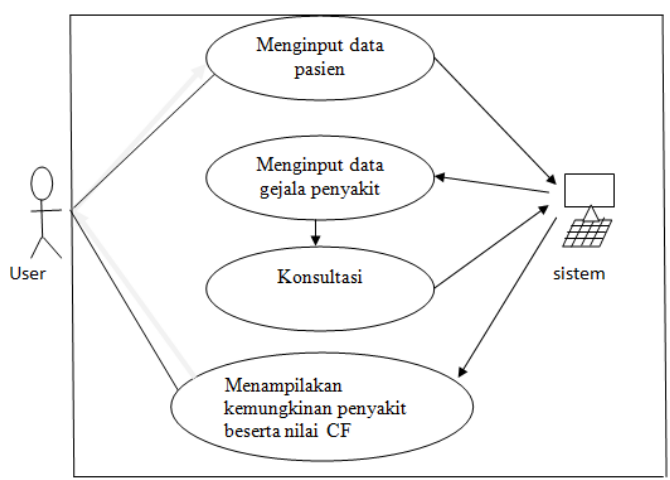

Gambar 2. Use case diagnosa penyakit kolestrol 


\subsection{Implementasi}

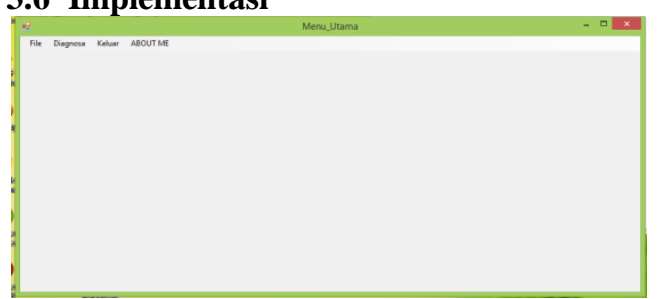

Gambar 3. Menu Utama

Input : memilihpilihan

Output : Tampilan

Proses :

Bila memilih file makatampilpilihandata Pasien, data Ciri-CiriGejala

Bila memilihDiagnosamakatampil form diagnosa Bila memilihabaoutmakatampil form tentangsaya Bila memilihkeluarmakaakankeluardari program:

\section{a. Form Data Pasien}

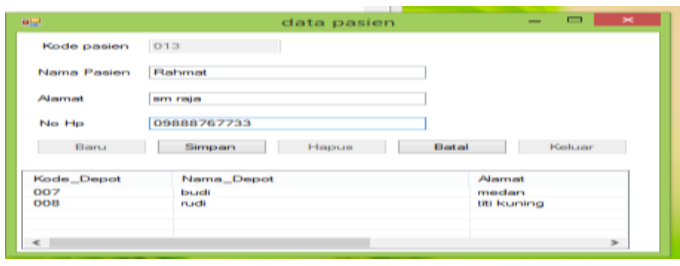

Gambar 4. Form Data Alternatif

Input : kodepasien, namapasien, alamat , no hp Output : Data pasien

Proses :

- Bila melakukan Penambahan maka klik Tombol "Baru"

- Isi Semua Field yang tersedia

- Tekan Tombol "Simpan" untuk menyimpan yang telah di buat tadi ke database

- Tekan tombol "Batal" untuk membatalkan ada di dalam form tersebut

- Bila melakukan Perubahan Data Lokasi

- Klik Data Grid yang tersedia, Sehingga data yang telah di pilih tersebut akan masuk ke dalam form

- Klik Tombol "Edit" bila ingin mengedit

- Edit Field yang tersedia sesuai dengan kebutuhan

- Tekan Tombol "Simpan" untuk menyimpan data yang telah di diedit ke database

- Tekan tombol "Batal" untuk membatalkan dan menghapus apa yang ada di dalam form tersebut

- Bila Melakukan Penghapusan Data

- Klik Data Grid yang tersedia, Sehingga data yang telah di pilih tersebut akan masuk ke dalam form

- Tekan Tombol "Delete" untuk menghapus data yang telah di tampilkan tersebut

- Tekan tombol "Batal" untuk membatalkan dan menghapus apa yang ada di dalam form tersebut.

\section{b. Form Data Ciri-Ciri Gejala.}

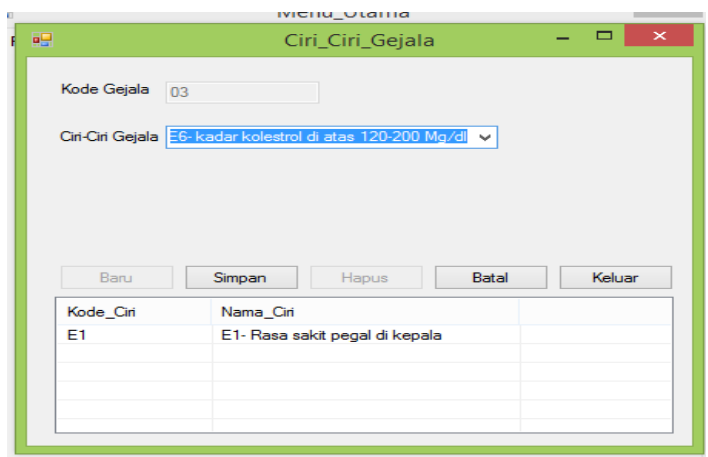

Gambar 5. Form Input Gejala

Input : kodeGejala, Ciri-CiriGejala

Output : Data Ciri-Cirigejala

Proses :

- Bila melakukan Penambahan maka klik Tombol "Baru”Isi Semua Field yang tersedia

- Tekan Tombol "Simpan" untuk menyimpan yang telah di buat tadi ke database

- Tekan tombol "Batal" untuk membatalkan ada di dalam form tersebutBila melakukan Perubahan

- Klik Data Grid yang tersedia, Sehingga data yang telah di pilih tersebut akan masuk ke dalam form

- Klik Tombol "Edit" bila ingin mengedit

- Edit Field yang tersedia sesuai dengan kebutuhan

- Tekan Tombol "Simpan" untuk menyimpan data yang telah di diedit ke database

- Tekan tombol "Batal" untuk membatalkan dan menghapus apa yang ada di dalam form tersebut

- Bila Melakukan Penghapusan Data

- Klik Data Grid yang tersedia, Sehingga data yang telah di pilih tersebut akan masuk ke dalam form

- Tekan Tombol "Delete" untuk menghapus data yang telah di tampilkan tersebut

- Tekan tombol "Batal" untuk membatalkan dan menghapus apa yang ada di dalam form tersebut

\section{c. Form Diagnosa}

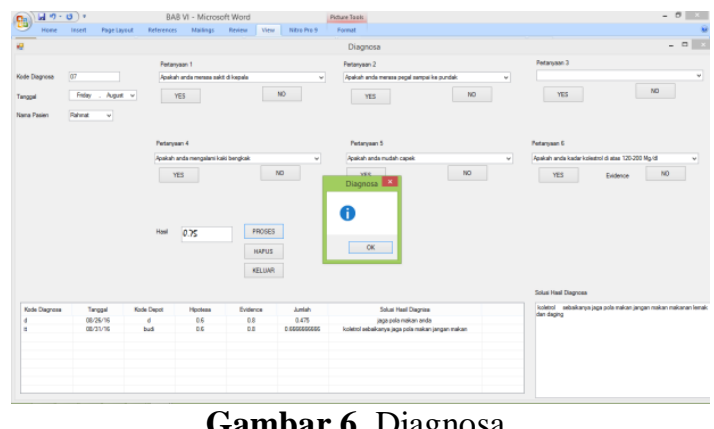


Input : Kodediagnose, tanggalnamapasien

Output : Hasil diagnose kolestrol

Proses :

- Bila melakukan Penambahan maka klik Tombol "Baru"Isi Semua Field yang tersedia.

- Tekan Tombol "Simpan" untuk menyimpan yang telah di buat tadi ke database.

- Tekan tombol "Batal" untuk membatalkan ada di dalam form tersebutBila melakukan Perubahan.

- Klik Data Grid yang tersedia, Sehingga data yang telah di pilih tersebut akan masuk ke dalam form..

- Klik Tombol "Edit" bila ingin mengedit.

- Edit Field yang tersedia sesuai dengan kebutuhan.

- Tekan Tombol "Simpan" untuk menyimpan data yang telah di diedit ke database.

- Tekan tombol "Batal" untuk membatalkan dan menghapus apa yang ada di dalam form tersebut.

- Bila Melakukan Penghapusan Data.

- Klik Data Grid yang tersedia, Sehingga data yang telah di pilih tersebut akan masuk ke dalam form.

- Tekan Tombol "Delete" untuk menghapus data yang telah di tampilkan tersebut.

- Tekan tombol "Batal" untuk membatalkan dan menghapus apa yang ada di dalam form tersebut

\section{Kesimpulan}

Berdasarkan uraian dari bab-bab sebelumnya, maka penulis dapat memberikan kesimpulan sebagai berikut :

1. Dalam prensentasi gejala penyakit kolestrol pada remaja memiliki 8 rule ( Aturan ) diagnosa yang selanjutnya dilakuakan basis pengetahuan untuk digunakan menentukan pasien menghidap penyakit kolestrol atau tidak.

2. Penerapan Metode Certainty Factor (CF) dapat mempermudah dan memberikan perhitungan penyelesain seberapa pasti para user mengetahui penyakit kolestrol pada remaja.

\section{Referensi}

[1] dr, Sri Nilawati, SpKO. 2008. b Your Self Kolestrol,. Yogyakarta. Penerbit C.V Andi Offset.

[2] T. Sutojo. 2011. Kecerdasan Buatan, Yogyakarta. Penerbit Graha Ilmu.

[3] Adhi Kusnadi. 2013. Perancangan Aplikasi Sistem Pakar Untuk Diagnosa Penyakit Pada Manusia. library.umn.ac.id/jurnal/.../cf1a586dead0f47 9bc5fb4add0331450.pdf. Waktu Akses 23 April 2014, 14:20 WIB.

[4] Annisa Trie Anna, Jurnal Hubungan Kadar Kolestrol LDL Dengan Tipe Stroke,

2012eprints.mdp.ac.id/.../JURNAL\%202007 $250062 \% 20$ MALIK\%20\%26\%20. Waktu Akses 23 April 2014, 18:05 WIB.

[5] T.sutojo, 2011," Certainty Factor", Andi,Yoyakarta, 